\title{
Traffic Effectiveness by Law Enforcement Community Through Which are Ticketed Traffic Law in Police of Pekalongan
}

\author{
Bobby Anugrah Rachman ${ }^{1}$, Anis Mashdurohatun ${ }^{2}$, Achmad Sulchan ${ }^{3}$
}

Abstract. This study aimed to analyze the effectiveness of enforcement by the Traffic through ticketed to the people who violate traffic in the jurisdiction of Police Pekalongan and analyze barriers to enforcement by the Traffic Police Pekalongan against people who commit traffic violations, as well as the solution.

The method used is empirical juridical approach or in other words the sociojuridical. Specifications research is descriptive. In this study the analysis used is qualitative analysis.

The results of this study were: 1) The enforcement of the law by speeding ticket Satlantas through to the people who violate traffic in the jurisdiction of Police Pekalongan have been effective. Law enforcement jurisdiction over a speeding ticket in Pekalongan Police can provide a deterrent effect against traffic offenders, violations be reduced and the number of traffic accidents decreased. 2) Obstacles and solutions enforcement by the Traffic Police Pekalongan against people who commit traffic violations include: Offenders traffic still does not have a deterrent effect because until now there are many traffic violations, the lack of personnel in the line of duty, inadequate number of vehicles Pekalongan is owned by traffic Police, there are still people who do not know about the traffic rules, there is still a cultural one, that there are parents that when her son gets ranking in school, then bought a motorcycle as a gift. The solutions or efforts made to overcome obstacles in enforcement by the Traffic Police Pekalongan: Enforcing the law indiscriminately through seminars and trainings, submitted a letter to the leaders for additional personnel, proposed the budget and facilities and amenities, add socialization schedule traffic rules, instilling a culture of orderly traffic among early age.

Keywords: Law Enforcement; Traffic Ticketed; Traffic Violations.

\section{Introduction}

The phenomenon of motorcycle users in Indonesia showed significant improvement. When compared to vehicle users car then the motorcycle so much more. Traffic violation case lately rife. In the case of traffic violations, based on the observations of researchers, although not found an exact figure the number of traffic violations committed on a public road vehicle users, traffic violations much more done by motorcyclists than other vehicle users.

In Pekalongan traffic condition is still relatively poor. This is evident from the results of a survey conducted at different points in the city of Pekalongan. There are still many good riders of motorcycles and private vehicles are not disciplined with traffic rules. Here is the table of data type of vehicle violations:

\footnotetext{
${ }^{1}$ Student of Master of Law, Universitas Islam Sultan Agung Semarang and Members of the Indonesian National Police (Polri), email: bobby@gmail.com

${ }^{2}$ Faculty of Law Universitas Islam Sultan Agung

${ }^{3}$ Faculty of Law Universitas Islam Sultan Agung
} 
Table 1

Data Breach by Type of Vehicle

Police Pekalongan in January to September 2018

\begin{tabular}{|c|l|r|}
\hline No. & \multicolumn{1}{|c|}{ Transportation Type } & \multicolumn{1}{c|}{ Total } \\
\hline 1 & Bus & 121 \\
\hline 2 & Truck & 1,463 \\
\hline 3 & Pick Up & 1,533 \\
\hline 4 & Mini bus & 2,399 \\
\hline 5 & Jeep & 348 \\
\hline 6 & Sedan & 379 \\
\hline 7 & Passenger car & 0 \\
\hline 8 & Metro Mini & 0 \\
\hline 9 & Taxi & 0 \\
\hline 10 & Wheels 3 & 11 \\
\hline 11 & Ransus & 0 \\
\hline 12 & Wheels 2 & 18,499 \\
\hline & Total & $\mathbf{2 4 , 7 5 3}$ \\
\hline
\end{tabular}

The type of violation committed the two-wheeler riders are as varied as not wearing a helmet, did not bring the letters completeness of a motor vehicle, in violation of road markings, against the flow and do not turn on the lights in daytime or light on. Traffic violations can not be left alone because it is based on existing data the majority of traffic accidents are caused due to human factors of road users who do not obey the traffic rules.

The efficient performance of the police need to be understood. In the law enforcement carried out by the Traffic Police, police existence of society depends on the behavior of its members. Increased traffic violations become a new challenge for the police to be able to apply sanctions that are educational but still have a deterrent effect. One way to suppress the offense is to perform administrative sanctions (ticketed) conducted by the police. Police give a ticket to those who committed a traffic violation.

Based on the authors are interested in doing legal research with the title "Traffic Effectiveness By Law Enforcement Community Through Which Are Ticketed Traffic Law In Police Of Pekalongan". Based on the above background, the issues to be discussed are: 1) How can the effectiveness of enforcement by the Traffic through ticketed to the people who violate traffic in the jurisdiction of Police Pekalongan? 2) What are the barriers to enforcement by the Traffic Police Pekalongan against people who commit a traffic violation and what's the solution?

\section{Research Methods}

The method used in this research is empirical juridical approach or in other words the socio-juridical. Specifications research is descriptive, because the specifics of this study 
aims to describe the problem in this research. ${ }^{4}$

Types and data sources can be divided into two, namely primary data and secondary data. Primary data were collected through interviews. Secondary data in this study of primary legal materials, secondary law, and tertiary legal materials.

Facilitate research in the cultivation of the research, carried out activities related to the processing and presentation of data is done by editing, ${ }^{5}$ coding after it conducted the data analysis.

Data analysis is the process of organizing the data so that the data can be interpreted. ${ }^{6}$ In this case the analysis of qualitative data is data which can not be measured or judged by the numbers directly. ${ }^{7}$

\section{Results And Discussion}

\subsection{Effectiveness Through Traffic Law Enforcement by Public Against Infringing Ticketed Traffic Police Jurisdiction of Pekalongan}

Effective derived from the English language is "effective" means something that is done successfully, or can be defined as the provision of use, effectiveness or support purposes. Etymologically, the word is defined as the effective serig mancapai desired target (producing desired result), impacted fun (having a pleasing effect), are actual, real (actual and real). ${ }^{8}$ Effectiveness is how well the work that has been done, the extent to which the results achieved someone / something. A job can be considered effective if done properly in accordance with the planned both its output and input.

Effectiveness demonstrated the ability to achieve goals that have been set according to prevailing standards. Effectiveness is more oriented to the output as it relates to the achievement of maximum performance in terms of attainment of targets relating to the quality, quantity and time. The enforcement by Traffic through ticketed to the people who violate traffic in the jurisdiction of Police Pekalongan have been effective. Brigadier Aulia Rahman following statement regarding the effectiveness of law enforcement through a ticket: "It is effective because it can reduce traffic accidents involving Pekalongan society." 9

The statement was reinforced by statements from Brigadier Ricky Juniawan which states that: "Effective enough to create a deterrent effect on traffic violators by giving such violations to pay a fine of Justice in the State Attorney Kajen." ${ }^{10}$

Based on these interviews, law enforcement through a speeding ticket in Pekalongan Police jurisdiction can provide a deterrent effect against traffic offenders, violations be reduced and the number of traffic accidents decreased. The presence of law enforcement through a ticket can be a solution in maintaining order and security of the

\footnotetext{
${ }^{4}$ Soerjono Soekanto, 2007, Pengantar Penelitian Hukum, UI Press, Jakarta, p. 51.

${ }^{5}$ Rony Hanitijo Soemitro, 1998, Metode Penelitian Hukum dan Jurimetri, Ghalia Indonesia, Jakarta, p. 35.

${ }^{6}$ Dadang Kahmad, 2000, Metode Penelitian Agama, CV Pustaka Setia, Bandung, p. 102.

${ }^{7}$ Tatang M. Aminrin, 1995, Menyusun Rencana Penelitian, PT. Raja Grafindo Persada, Jakarta, p. 134.

${ }^{8}$ Nyoman Sumaryadi, 2005, Efektifitas Implementasi Kebijakan Otonomi Daerah, Citra Utama, Jakarta, p. 4.

${ }^{9}$ Interview with Brigadier Aulia Rahman, as members of the Police Pekalongan dated 9 November 2018

${ }^{10}$ Interview with Brigadier Ricky Juniawan, as members of the Police Pekalongan dated 9 November 2018
} 
rider or other road users.

It is strengthened by the data reduction in the number of traffic violations in Pekalongan for 3 (three) years outlined in the table below:

Table 2

Data Reduction in Violations Based on Police Vehicle Type of Pekalongan of 2016$2018^{11}$

\begin{tabular}{|l|l|r|r|r|}
\hline \multirow{2}{*}{ No. } & \multirow{2}{*}{$\begin{array}{c}\text { Transportation } \\
\text { Type }\end{array}$} & \multicolumn{3}{|c|}{ Year } \\
\cline { 3 - 5 } & \multicolumn{1}{|c|}{$\mathbf{2 0 1 6}$} & $\mathbf{2 0 1 7}$ & \multicolumn{1}{|c|}{$\mathbf{2 0 1 8}$} \\
\hline 1 & Bus & 187 & 155 & 121 \\
\hline 2 & Truck & 2,092 & 1,821 & 1,463 \\
\hline 3 & Pick Up & 1,828 & 1,661 & 1,533 \\
\hline 4 & Mini bus & 2,877 & 2,524 & 2,399 \\
\hline 5 & Jeep & 441 & 409 & 348 \\
\hline 6 & Sedan & 437 & 411 & 379 \\
\hline 7 & Passenger car & 21 & 14 & 0 \\
\hline 8 & Metro Mini & 15 & 7 & 0 \\
\hline 9 & Taxi & 13 & 7 & 0 \\
\hline 10 & Wheels 3 & 23 & 18 & 11 \\
\hline 11 & Ransus & $\mathbf{7}$ & 2 & 0 \\
\hline 12 & Wheels 2 & $\mathbf{2 2 , 9 3 1}$ & 21,114 & 18,499 \\
\hline & Total & $\mathbf{3 0 , 8 7 2}$ & $\mathbf{2 8 , 1 4 3}$ & $\mathbf{2 4 , 7 5 3}$ \\
\hline
\end{tabular}

Traffic violation (hereinafter referred to ticketed) is a social phenomenon and legal issues that require effective management and efficient to enable the orderly traffic and legal awareness in the implementation of Act No. 22 of 2009 regarding Traffic and Road Transportation. Procedures for handling cases of traffic violations in Indonesia at this time is set by reference to Act No. 22 of 2009 regarding Traffic and Road Transportation (Act LLAJ) which replaces Act No. 14 of 1992 regarding Traffic and Road Transport and Act No. 8 of 1981 on Criminal Proceedings.

Although law enforcement is done by Traffic through ticketed for traffic violators in Pekalongan have been effective and can provide a deterrent effect to offenders, but the Act No. 22 of 2009 regarding Traffic and Road Transportation (LLAJ Act) which replaced the Act No. 14 of 1992 regarding Traffic and Road Transport and Act No. 8 of 1981 on Criminal Procedure Code has not yet been effective. It is said is still not effective, because there are many motorists who violate traffic, such as school children who are not old enough still much to bring the motorcycle to school. But the effort or the effort of Traffic of Pekalongan Police has a maximum, both in terms of pre-emptive, preventive and repressive.

The phenomenon of the traffic chaos that is most visible during peak hours (between the hours of 6:30 to 8:00 a.m.), where time is a time of school activities and workers. The observations made at the point of police stations across the city traffic Pekalongan seen many violations committed by school children, by not wearing a helmet,

${ }^{11}$ Traffic Police Pekalongan. 
especially tandem. ${ }^{12}$ You can imagine when a student who uses a motor vehicle, let alone at the high school level is still equal even junior level there is also dared to bring a motor vehicle on a highway. ${ }^{13}$

As for the cause of a traffic violation in Pekalongan region is very diverse. The following statement Akhmad Fauzi expressed as a police officer in the area of Pekalongan states that: "Awareness of community law is still very low, despite the existing proven prohibition sign for passing and no national police officers on guard at the venue, but they still break through to the ban." ${ }^{14}$

Legal consciousness is a process that includes elements of legal knowledge, understanding of the law, the attitude of law and legal behavior. The level of legal awareness achieved if people obey the law. Enforcement of traffic laws and road transport. One person's basic adherence to the law is a habit. People obey the rules in force since childhood experienced a process of socialization so that compliance with the rules has become a habit.

In the case handling traffic violations, as well as the handling of criminal cases in general involving the Police and Civil Servant Investigators, prosecutors, and courts. Investigative authority handed over to the Police and investigators fields Traffic and Road Transport with far more authority in the hands of the police.

Each traffic violation will be dealt with by the investigator based on their authority. In the examination of fast event for road traffic violations cases no investigation report (article 212 Criminal Code) so that proof of violations (speeding ticket) directly sent to the court by the investigator. As proof of violations (speeding ticket) issued Satlantas to people who commit traffic offenses in the jurisdiction of Police Pekalongan there are two types.

Based on the interview can be seen that offenders can choose to attend the hearing in the prosecutor's office and pay a fine determined by a judge or fine ticketed through designated banks. In the ticket is determined the time and place of the hearing to those who choose to attend the hearing.

Based on the Decree of the Head of Police No. Pol .: SKEP / 443 / IV / 1998 on Technical Reference Guide on the Use Blank Ticketed, offenders entitled to reject the allegation of the offense with the consequences of foreclosure of certain goods by the investigator until the trial is completed, or accept the supposition that continued with fund deposits maximum fine set by law LLAJ through Bank appointed by the Government without any foreclosure. Seizure of police investigators to do as a guarantee that offenders will be attending the hearing. These fines will be non-tax revenue from the Police.

\subsection{Barriers and Solutions by Traffic Police of Pekalongan in Law Enforcement Against Community Traffic Violations}

Application of a ticket is an effective option to reach the target in the implementation

\footnotetext{
${ }^{12}$ Arfan, Andi. Penegakan Hukum Bagi Pengemudi Kendaraan Roda Dua Di Bawah Umur Tanpa Surat Izin Mengemudi Di Wilayah Hukum Polisi Resor Kota Pekanbaru Berdasarkan Undang-Undang Nomor 22 Tahun 2009 Tentang Lalu Lintas Angkutan Jalan. JOM Fakultas Hukum 1 No. October $2^{\text {nd }}, 2014$

${ }^{13}$ Sudarsono, Kenakalan Remaja, Rineka Cipta, Jakarta, 2004, p. 5.

${ }^{14}$ Interview with Ipda Akhmat Fauzi, as members of the Police Pekalongan dated 9 November 2018
} 
of the rule of law to violators of traffic regulations. Nevertheless in law enforcement for traffic violations committed by the community there are several obstacles faced by the Traffic Police Pekalongan. Based on the interview can be concluded that there are several factors the barriers faced by law enforcement through ticketed for traffic violations in the jurisdiction of Police Pekalongan namely:

- Law itself; To achieve a deterrent effect as a result of a traffic ticket offense should be tested by how sure someone will be punished (if paying fines or seized vehicles) in advance. Given the severity of fines (or fines) imposed does not necessarily make offenders not to repeat his actions it will allow the person to repeat the offense because there is no disincentive to do so. In another sense, traffic violators still do not have a deterrent effect because until now there are many traffic violations.

- Law Enforcement Factors; One of the factors considered as obstacles in carrying out patrols is the lack of personnel in the line of duty. Due to limited personnel Satlantas so it can not reach the entire region Pekalongan and resulted in persistence of the actors who Extortion (Illegal Payments) and therefore can not educate offenders.

- Facilities and Amenities; Barriers faced by Traffic Police Pekalongan against factor is the lack of facilities for the number of vehicles owned by the Traffic Police Pekalongan to do counseling in Pekalongan Police across jurisdictions.

- Community; There are still people who do not know about the traffic rules in general and age for students who can get a driver's license under the Act No. 22 of 2009 regarding Traffic and Road Transportation.

- Culture; There is still a cultural one, that there are parents that when her son gets ranking in school, then bought a motorcycle as a gift. In this case, the parents are the primary key that causes children to use the motor. With the permission of the parents, the child can use a bike to school or to play.

Law enforcement is one of the important efforts in creating peace of order in society, both preventive and repressive, after the occurrence of violations of the law. Obstacles faced by the traffic police unit in the imposition of sanctions is quite difficult for a speeding ticket in Pekalongan Police jurisdiction. Thus the traffic police have made several attempts to overcome the barriers in law enforcement through a speeding ticket in Pekalongan Police jurisdiction, namely:

- Law Itself; Each member of the police traffic unit Pekalongan Police to carry out duties in accordance with applicable rules, and enforce the law indiscriminately, through seminars and trainings. The judge is also expected to be convicted of a traffic violation by giving maximum fines to the offender the hopes of providing a deterrent effect so that offenders do not repeat the offense again.

- Factors Law Enforcement; Efforts should do is submit a letter to the leaders for additional personnel and crack down on rogue officer who made the extortion. The more the number of personnel who patrol it will be more knowledgeable to the area combed by the police.

- Facilities and Amenities; In addressing complaints against the lack of infrastructure and operational budgets for the traffic police, especially when doing outreach to the villages, the traffic police in this case remains to do its job, although hit by infrastructure and budget are minimal. Besides the traffic police has proposed 
additional budget and facilities and facilities to the leadership to increase, improve the signs or banners calling on traffic safety.

- Community; To raise public awareness about the importance of obeying traffic laws, police in the jurisdiction of Police Pekalongan can be done by: Adding socialization schedule traffic rules; Build trust by doing action of the heart, showed that the actions of police officers are sincere, honest, open and responsible to provide security, maintain the safety, serve, protect and guide the community;

- Culture; Efforts are underway Traffic Police Pekalongan are plunges into the housing complex and to the village and to provide education about the dangers of giving the motor to children who are not old enough. Brigadier Ricky Juniawan, as members of the Police Pekalongan identifies, it was pocketed some of the programs that actively been executed.

\section{Closing}

\subsection{Conclusion}

Based on the discussion of the problems under study, the conclusions of this study are as follows:

- Traffic enforcement by the public through the ticket against traffic violations in the jurisdiction of Police Pekalongan have been effective. Law enforcement jurisdiction over a speeding ticket in Pekalongan Police can provide a deterrent effect against traffic offenders, violations be reduced and the number of traffic accidents decreased.

- Obstacles and solutions enforcement by the Traffic Police Pekalongan against people who commit traffic violations include: Violators of the law itself $=$ traffic still does not have a deterrent effect because until now there are many traffic violations; Factor = Lack of law enforcement personnel in the line of duty; The lack of facilities = the number of vehicles owned by the Traffic Police Pekalongan; Community = There are still people who do not know about the traffic rules; Culture $=$ There are still cultural one, that there are parents that when her son gets ranking in school, then bought a motorcycle as a gift.

- The solutions or efforts made to overcome obstacles in enforcement by the Traffic Police Pekalongan: Law itself $=$ uphold the law indiscriminately through seminars and trainings; Law enforcement Factor = Asking a letter to the leaders for additional personnel; Facilities and amenities = Asking a budget increase and the means and facilities to the leadership; Community = Add socialization schedule traffic rules; Culture $=$ Embedding orderly traffic culture among early age.

\subsection{Suggestion}

Based on the above conclusions, the authors formulate suggestions related to this study as follows:

- Party Traffic Police Unit should improve and maximize its performance in order to improve security, public order, any violations must be prosecuted and penalized the firm, in terms of enforcing the law indiscriminately.

- Indonesian National Police in particular in order to further optimize the Pekalongan Police enforcement programs through ticketed to reduce traffic violations in the 
jurisdiction of Police Pekalongan.

\section{Bibliography}

[1] Dadang Kahmad, 2000, Metode Penelitian Agama, CV Pustaka Setia, Bandung.

[2] Nyoman Sumaryadi, 2005, Efektifitas Implementasi Kebijakan Otonomi Daerah, Citra Utama, Jakarta.

[3] Rony Hanitijo Soemitro, 1998, Metode Penelitian Hukum dan Jurimetri, Ghalia Indonesia, Jakarta.

[4] Soerjono Soekanto, 2007, Pengantar Penelitian Hukum, UI Press, Jakarta.

[5] Sudarsono, Kenakalan Remaja, Rineka Cipta, Jakarta, 2004.

[6] Tatang M. Aminrin, 1995, Menyusun Rencana Penelitian, PT. Raja Grafindo Persada, Jakarta.

[7] Arfan, Andi, Penegakan Hukum Bagi Pengemudi Kendaraan Roda Dua Di Bawah Umur Tanpa Surat Izin Mengemudi Di Wilayah Hukum Polisi Resor Kota Pekanbaru Berdasarkan Undang-Undang Nomor 22 Tahun 2009 Tentang Lalu Lintas Angkutan Jalan. JOM Fakultas Hukum Volume 1 No. October $2^{\text {nd }}, 2014$ 